\title{
PENGUATAN UKS MELALUI PELATIHAN PENENTUAN STATUS GIZI BAGI GURU UKS SEKOLAH DASAR DI KABUPATEN SLEMAN, YOGYAKARTA
}

\author{
Tri Siswati ${ }^{1}$ dan Herawati ${ }^{2}$ \\ ${ }^{1}$ Health Polytecnic of Ministry of Health Yogyakarta \\ ${ }^{1}$ Email: trisiswati14@gmail.com \\ ${ }^{2}$ Email: hera.jogja@yahoo.com
}

\begin{abstract}
ABSTRAK
Pelatihan guru UKS dalam hal penilaian status gizi dengan antropometri diharapkan dapat mendukung upaya pemerintah dalam akselerasi UKS. Pelatihan dapat mengembangkan kapasitas petugas UKS dalam menjalankan fungsinya sebagai petugas health promoting school. Pelatihan terbatas pada 32 guru UKS, sehingga perlu dilakukan pelatihan bagi sekolah lain termasuk sekolah menengah pertama dan atas dengan substansi materi yang disesuaikan dengan tahapan tumbuh kembang siswa. Sebagian besar peserta berasal dari SD negeri $(68,6 \%)$, laki-laki (59,4\%), 31-40 tahun (34,4\%), guru pendidikan jasmani/olah raga (65,5\%), mengelola UKS sejak tahun 2010 (37,5\%) dan belum pernah mendapat pelatihan serupa yang diberikan peneliti $(94,8 \%)$ Pelatihan merupakan cara yang efektif dalam meningkatkan skor pengetahuan dan ketrampilan peserta dalam hal pengukuran status gizi. pelatihan ini dapat meningkatkan pengetahuan dan ketrampilan. Pelatihan penilaian status gizi bagi guru UKS sangat diperlukan untuk mendukung health promoting school dan mendukung keberhasilan pemerintah dalam upaya akselerasi UKS.
\end{abstract}

Kata kunci: Guru; Pelatihan; SD; UKS.

\section{PENDAHULUAN}

Kesehatan siswa adalah faktor yang penting yang mempengaruhi proses pertumbuhan, perkembangan dan pencapaian prestasi belajar siswa (UU Kesehatan No 39 tahun 2009). Bahkan dalam jangka panjang kesehatan mendukung peluang pencapaian jenjang pendidikan yang lebih tinggi dan pekerjaan yang baik sehingga mereka tumbuh menjadi dewasa yang mampu membangun finansial ekonomi mikro dan makro (WHO).

Pengukuran status gizi melalui antropometri adalah salah satu cara deteksi dini hambatan pertumbuhan bagi anak-anak. Secara rutin di bawah koordinasi Puskesmas, pengukuran pada anak baru masuk sekolah/ tinggi badan anak baru sekolah (TBABS) menjadi salah satu alat screening kesehatan anak. Tinggi badan yang kurang diasumsikan sebagai akibat kurang gizi jangka panjang yang dapat mengganggu prestasi belajar siswa dan ketahanan tubuh terhadap penyakit rendah (Adair et al., 2013; Hoddinott et al., 2013) dan angka kematian anak (Tiwari et al., 2014). Malnutrisi jangka panjang juga menyebabkan gangguan perkembangan dan produktivitas yang rendah saat dewasa nantinya (Chirande et al., 2015; Tiwari et al., 2014).

Di lingkup sekolah, UKS merupakan ujung tombak upaya "health promotion school". UKS bertujuan untuk meningkatkan kemampuan hidup sehat bagi siswa, sehingga siswa dapat belajar, tumbuh, dan berkembang secara harmonis dan setinggi-tingginya menjadi sumber daya manusiayang berkualitas. Meskipun UKS dirintis sejak tahun 1956 antara Departemen Kesehatan, Departemen Pendidikan dan Departemen Dalam Negeri, namun capaian program ini sangat bervariasi antar daerah. Sehingga pemerintah menginstruksikan akselerasi UKS pada tahun 2015, dengan cara menggali, memanfaatkan dan memaksimalisasi semua potensi sumber daya yang tersedia serta memperkuat kemitraan dengan semua pemangku kepentingan. Salah satu strategi yang dilaksanakan adalah pengembangan kapasitas sumber daya manusia yang bertugas di UKS. 
Berdasarkan beberapa referensi pelatihan merupakan cara yang efektif untuk meningkatkan pengetahuan dan ketrampilan tenaga kesehatan. Pelatihan memberikan kesempatan kepada peserta untuk mengerti, memahami, melakukan simulasi dan demonstrasi pada situasi riil sehingga mendapatkan pengetahuan dan ketrampilan yang tinggi. pelatihan atau psikoedukasi menurut Supratiknya (2011) merupakan pengembangan dan pemberian informasi dalam bentuk pendidikan masyarakat mengenai informasi yang berkaitan dengan psikologi populer/sederhana atau informasi lain yang mempengaruhi kesejahteraan psikososial masyarakat. Pemberian informasi ini bisa menggunakan berbagai macam media dan pendekatan. Psikoedukasi bukan merupakan suatu pengobatan, namun hal ini dirancang untuk menjadi bagian dari rencana perawatan secara keseluruhan.

Pelatihan guru UKS dalam hal penilaian status gizi dengan antropometri diharapkan dapat mendukung upaya pemerintah dalam mengembangkan kapasitas petugas UKS, sehingga mereka dapat menjalankan fungsinya sebagai petugas health promoting school.

\section{METODE PELAKSANAAN}

Kegiatan dilaksanakan dalam bentuk pelatihan selama 30 Jam Pembelajaran Latihan terbagi menjadi tiga (3) hari. Pelaksanaan diadakan pada setiap hari Sabtu selama 3 minggu berturut-turut pada bulan Juli tahun 2016. Peserta adalah 32 orang guru Usaha Keshatan Sekolah (UKS) dari 20 Sekolah Dasar (SD) wilayah Kabupaten Sleman. Masing-masing sekolah diwakili 1 hingga 2 orang. Kegiatan dilaksanakan di Ruang Rapat Politeknik Kesehatan (Poltekkes) Kemenkes Yogyakarta,, tepatnya pada ruang pelatihan yang sangat memadai,. Hal ini didukung oleh kelengkapan peralatan pembelajaran antara lain LCD dan mikrofone, serta suasana pelatihan hening karena mahasiswa dan perkantoran libur. Untuk menunjang keberhasilan pelatihan, peserta diberi modul, di fasilitasi oleh para ahli sebgai pelatihnya dengan metode ceramah, tanya jawab, simulasi, demonstrasi dan praktek.

\section{HASIL DAN PEMBAHASAN}

Analisis data dilakukan untuk mendapatkan gambaran mengenao pengetahuan dan ketrampilan para peserta pelatihan. Ditinjau dari demografi peserta, sebagian besar sampel berasal dari Sekolah Dasar negeri (68,6\%), laki-laki (59,4\%), 31-40 tahun (34,4\%), guru pendidikan jasmani/olah raga (65,5\%), mengelola UKS sejak tahun 2010 (37,5\%) dan belum pernah mendapat pelatihan serupa yang diberikan peneliti $(94,8 \%)$ tercantum dalam gambar 1. Pelatihan terselenggara dengan baik, dengan dokumentasi kegiatan pada gambar 2 dan gambar 3. 


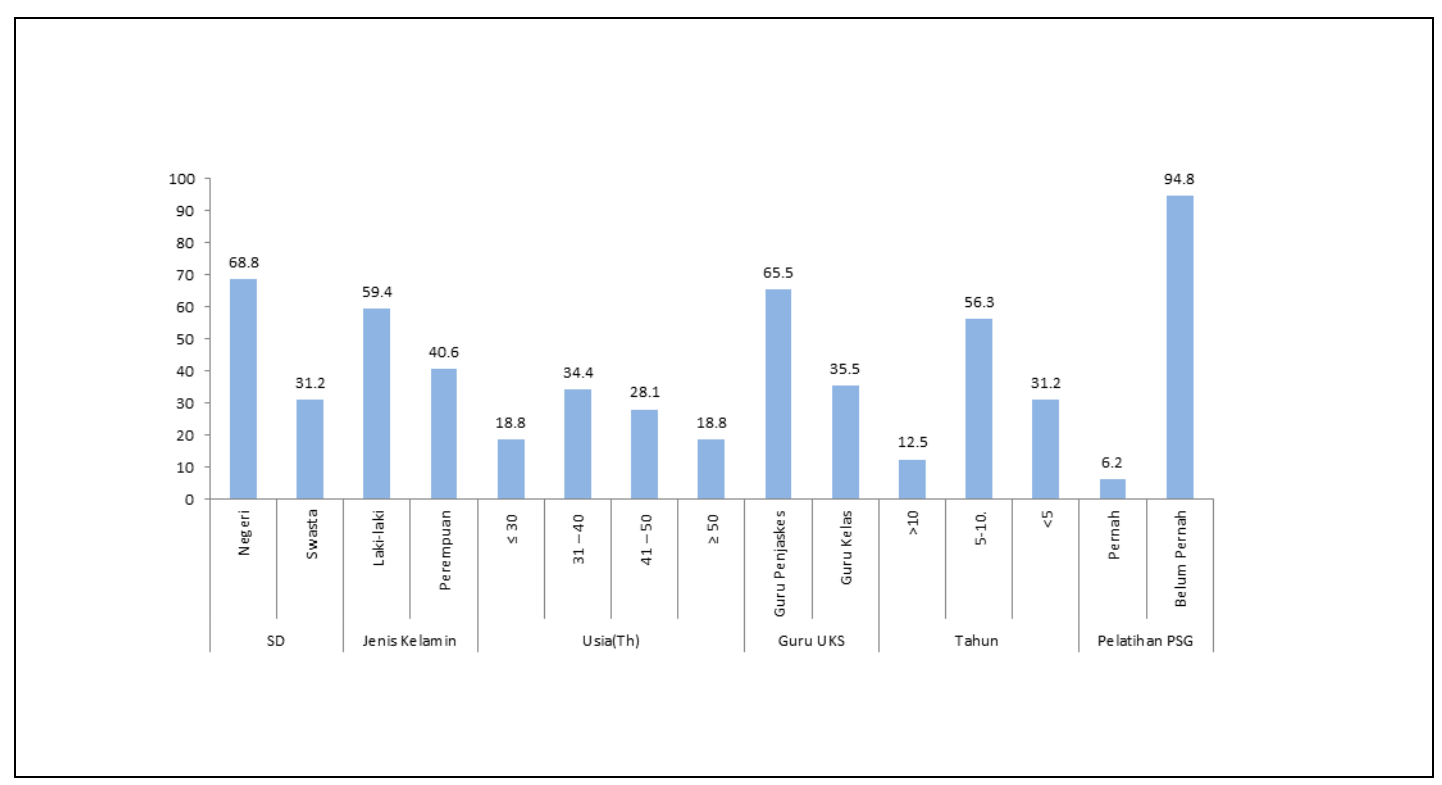

Gambar 1. Karakteristik Peserta Pelatihan

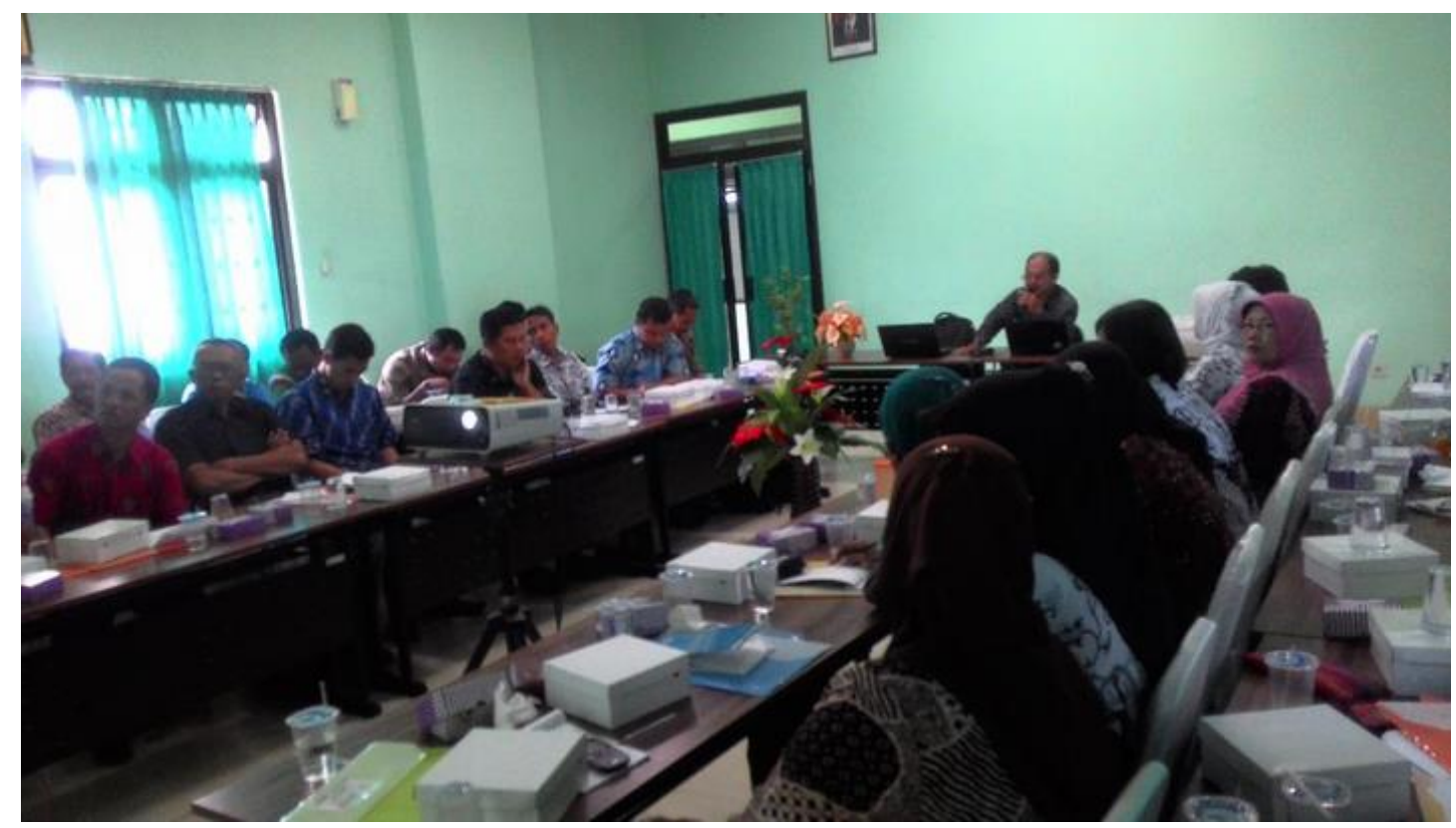

Gambar 2. Pelaksanaan Pelatihan (1) 


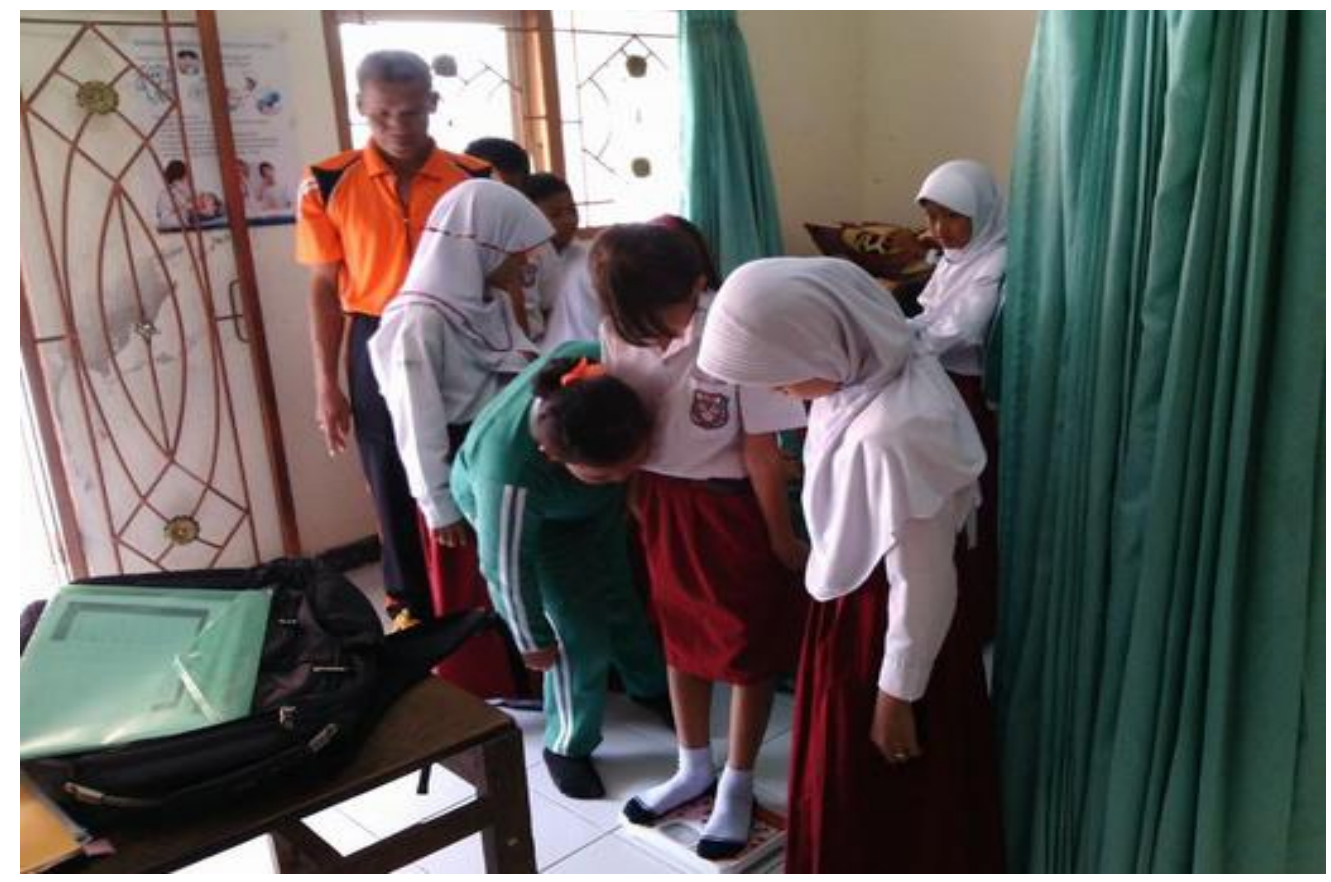

Gambar 3. Pelaksanaan Pelatihan (2)

Untuk mengetahui keberhailan pelatihan atau psikoedukasi health promoting school pada peserta mellaui penilaian status gizi bagi guru UKS penulis melakukan analisis atau evaluasi dengan melakukan tiga kali (pretest, posttest dan delta). Hasil analisis atau evaluasi peserta secara lebih lengkap, ditunjukkan pada gambar 3 di bawah ini. Melalui pengukuran status gizi , maka pelatihan atau psikoedukasi mampu meningkatkan pengetahuan dan ketrampilan peserta mengenai health promoting school.

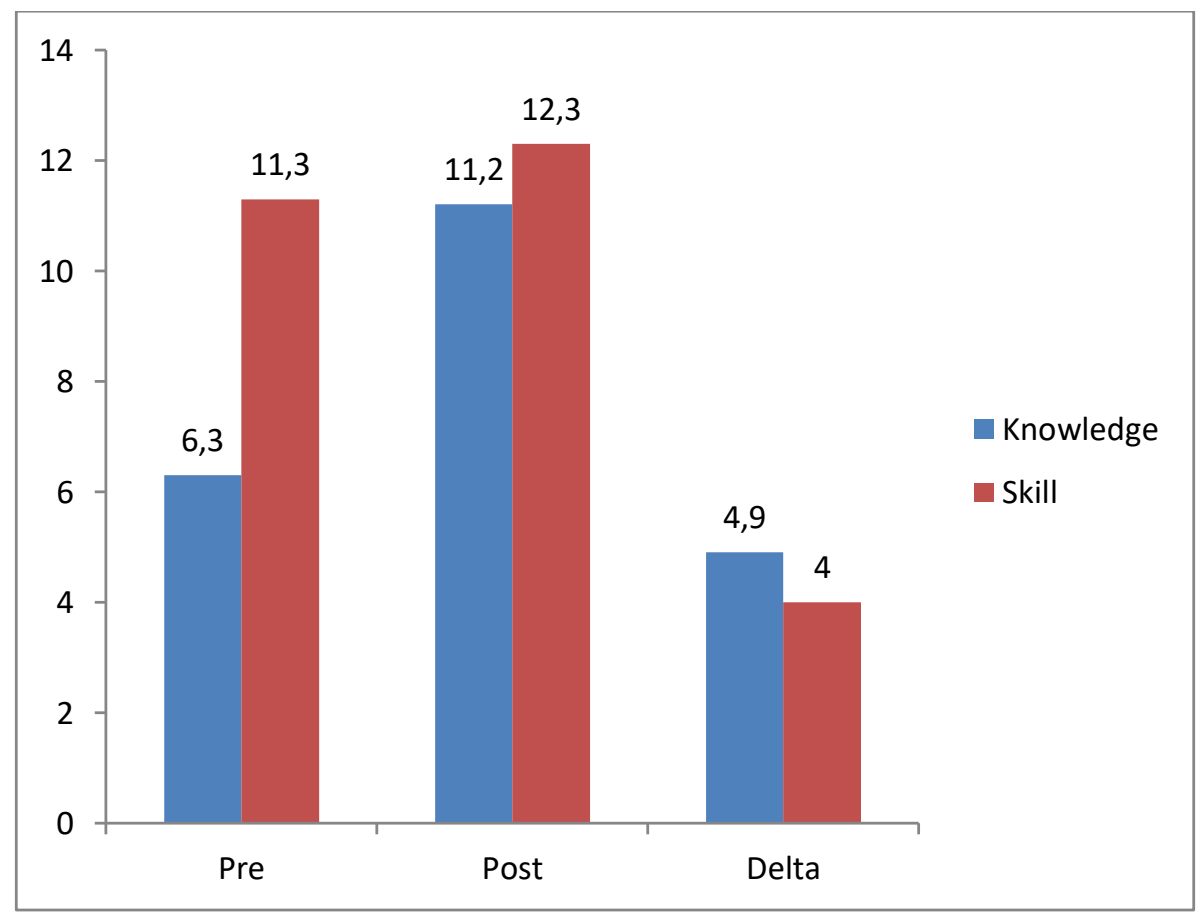

Gambar 3. Peningkatan pengetahuan dan ketrampilan peserta pelatihan 


\section{KESIMPULAN}

Melalui suatu kegiatan pemberian informasi dalam bentuk pendidikan bagi para guru UKS SD di wilayah Kabupaten Sleman mengenai penilaian status gizi masyarakat dalam rangka kesejahteraan siswa SD, kegiatan pelatihan atau psikoedukasi health promoting school dilakukan. Pelatihan penilaian status gizi bagi guru UKS sangat diperlukan untuk mendukung health promoting school dan mendukung keberhasilan pemerintah dalam upaya akselerasi UKS. Kegiatan ini terbatas pada 20 sekolah dasar, sehingga perlu dilakukan pelatihan bagi sekolah lain termasuk sekolah menengah pertama dan atas dengan substansi materi yang disesuaikan dengan tahapan tumbuh kembang siswa.

\section{Ucapan Terima Kasih (Acknowledgement)}

Ucapan terima kasih disampaikan kepada para peserta pelatihan, dan pimpinam Poltekes Kemenkes Yogyakarta, sehingga kegiatan pengabdian kepada masyarakat dapat dilaksanakan dengan baik. Serta pihak-pihak yang mendukung kegiatan ini.

\section{REFERENSI}

Adair, L.S., Fall, C.H.D., Osmond, C., Stein, A.D., Martorell, R., Ramirez-Zea, M., Sachdev, H.S., Dahly, D.L., Bas, I., Norris, S.A., Micklesfield, L., Hallal, P., Victora, C.G., (2013). Associations of linear growth and relative weight gain during early life with adult health and human capital in countries of low and middle income: Findings from five birth cohort studies. Lancet 382, 525-534.

Chirande, L., Charwe, D., Mbwana, H., Victor, R., Kimboka, S., Issaka, A.I., Baines, S.K., Dibley, M.J., Agho, K.E. (2015). Determinants of stunting and severe stunting among under-fives in Tanzania: evidence from the 2010 cross-sectional household survey. BMC Pediatr. 15 , $165 . \mathrm{b}$

Hoddinnot, J., Alderman H, Behrman JR, Haddad L, Horton S., (2013.) The economic rationale for investing instunting reduction. Maternal and Child Nutrition, 9 (Suppl. 2), pp. 69-82

Kemenkes RI, (2009,) Undang-Undang Kesehatan No 39 Tahun 2009, Jakarta. http://www.depkes.go.id/resources/download/general/UU\%20Nomor\%2036\%20Tahun2 $\% 20009 \% 20$ tentang\%20Kesehatan.pdf

Kemenkes RI (2015), Pedoman Akselerasi UKS, Jakarta. http://kesga.kemkes.go.id/images/pedoman/pedoman\%20aksel\%20UKS-2016.pdf

Tiwari, R., Ausman, L.M., Agho, K.E., 2014. Determinants of stunting and severe stunting among under-fives : evidence from the 2011 Nepal Demographic and Health Survey. BMC Pediatr. $14,1-15$

Supratiknya, A.(2011). Merancang Program Dan Modul Psikoedukasi. Edisi Revisi. Yogyakarta : Universitas Sanata Dharma.

WHO. Health promoting school. https://www.who.int/health-promoting-schools/en/ 